\title{
GMo FP Must be a technological progress
}

\author{
Mammed Agagulu Najafzadeh ${ }^{1}$, Natalia Sergeyevna Beryoza ${ }^{2}$ \\ ${ }^{1}$ Translator of the Botany Institute of the Azerbaijan NAS, AZ 1073, 40-Badamdar Shosse, Baku, Researcher of the Institute of \\ Linguistics of the ANAS \\ ${ }^{2}$ Junior Scientific Worker of Bioactive Compounds Lab of the Research Institute of Pharmacy First Moscow State Medical University \\ named after I. M. Sechenov
}

Email address:

nadjafzadeh@rambler.ru(M. A. Najafzadeh)

To cite this article:

Mammed Agagulu Najafzadeh, Natalia Sergeyevna Beryoza. GMo FP Must Be a Technological Progress. European Journal of Biophysics. Vol. 1, No. 3, 2013, pp. 28-32. doi: 10.11648/j.ejb.20130103.11

\begin{abstract}
It's not a secret that today the problem of GMo FP (genetically modified food plants) is one of the main problems in all over the world that stands face-to-face with the mankind. Of course it was invented to achieve food abundance as there are many countries of Asia and Africa where children suffer of hunger GMo FP should be welcomed. However it's known to everybody what harmful and dangerous results exist in this innovation as geneticists know that farmers use genes of various animals and organisms in cultivation of such products. It can become to unsolvable problems of humanity in the nearest future in the case of remaining it beyond controle. Also a comparative linguistic analysis of the used terminology is given in the article.
\end{abstract}

Keywords: Genetically Modified Food Plants, Bioterrorizm, Unsolvable Problems

\section{Introduction}

GMo FP is a field in Biotechnics called 'Gene engineering' that is related with gene transfer from alien organisms. As a result the obtained hybrid organisms are known as genetically modified food plants - Gene Engineering'. In 1972 Paul Dev ascertained a new combinant microorganism by gene transferring to a microorganism from three sources. But he recognized himself that in the case of releasing such organisms into the environment not ensuring and without checking them up they can go out of control and become unprevented. The scientists having a presentiment of the upcoming danger together with his colleagues signed a declaration about not releasing such organisms into the environment to be considered as dangerous while they aren't completely proved as safe ones. However these methods have been developed. According to Azerbaijan biologists each method developed in the GMo FP field has got its own lacks. "Even today there is not an improved complete method that our scientists could be sure a transferred gene in what form is in mutual relationship with other genes as well as the bioactive substances originated the gene transformation are not only desirable but how they can effect onto the other properties. Despite all of these, the methods have widely spread in all over the world after their development. These methods gave an opportunity for the scientists creating genetically modified microorganism, alive hybrid organisms of plant or animal origin by conducting genetic manipulations in the most different organisms" - said E.Aliyev, A Senior Scientific Worker of the Husbandry Institute of the Azerbaijan Agrarian Ministry. [We are opposite to bioterror of GMo FP. www.olaylar.az.21Apr.,2011, N61 (2761), p.10].

\section{Discussion of the Research}

Experimental activities carried out in Argentina, Australia, Indonesia and Russia clearly showed that GMo FP are not perfect and are of special/extreme danger. According to E.Aliyev GMo FP analogues have been created in more than 120 various agricultural plants at present. Referred to the latest information 64 of them are being applied in the farm fields. Agricultural plants with GMo organisms are cultivated in 23 countries. Egypt is the least country that includes the list where GMo FP is cultivated. Such organisms are applied to the 1-st generation of human beings at present. What negative results and consequences may occur in the 2-nd and 3-rd generations our progeny can see only?

Azerbaijan formerly popular with its natural and ecologically pure plants, for instance: white apple of Guba; 
'Gyzyl Ahmedi' apple variety; chestnut of Gabala; watermelon of Sabirabad; melon of Kurdamir; pomegranate varieties of Gekchay; potato of Gedabek; white onion of Hovsan Village (Baku Suburb); 'White Shany' and 'Black Shany' varieties of grapes; almond, olive, 'Khar Tut' variety of mulberry and fig cultivated in Baku Suburbs for centuries; citrus plants, tea and vegetable of Lankaran; hazelnut, walnut, attar of roses and persimmon of Zagatala; apricot, peach, apple and walnut of Ordubad; quince and cherry plum of Agdash; cherry, crab/sweet cherry (merry) and tomato of Khachmaz. It is possible to develop this list. Unfortunately there are enough GMo FP in this unique land at present. Such food products can be met in every step of Baku Markets.

Azerbaijan experts suppose it is just the time to shout SOS right now. Azerbaijan is a unique region and it is an hotbed of many crops and cultivated plants origin. Implementation of such experiments may cause undesirable results in such a region. I am worried because of possible effects onto the human health. Problems of such GMo fruits and vegetables are known by everybody. Even in the information of some international organizations it's clearly explained that risk potentiality of such GMo FP for health is high. So, GMo FP cause other allergic diseases, even cancer is not an exception.

Table 1. Table of comparative linguistic analysis of the used terminology

\begin{tabular}{|c|c|c|c|}
\hline English & Russian & Latin & Azerbaijani \\
\hline alien organisms['e1lın 'o:gənızmz] & живые организмы & alien organizmeae & canlı orqanizmlər \\
\hline almond[' $\alpha:$ mənd] & миндаль & Amygdalus & badam \\
\hline biochemist [, baiəu'kemıst] & биохимик & biochemist & biokimyaçı \\
\hline cherry ['tjer1] & вишня & Cerasus & albalı \\
\hline cancer ['kæn(t)sə] & рак & carcinoma & xərçəng \\
\hline cherry plum ['tjerı $\mathrm{pl} \Lambda \mathrm{m}]$ & терем & Prunus spinosa & göyəm \\
\hline chestnut ['tjesnət] & каштан & Castanea & şabalıd \\
\hline crab/sweet cherry['sw1:t 'tjerı] & черешня & Cerasus avium & gilas \\
\hline fig [fig] & инжир & Ficus carica & oncir \\
\hline gene engineering $\left[{ }^{\prime} \mathrm{d}\left[1: \mathrm{n}\right.\right.$ ind $\left[\mathrm{I}^{\prime}\right.$ nıərı $]$ & генная инженерия & genum engineeria & gen mühəndisliyi \\
\hline $\begin{array}{l}\text { genetically modified food plants } \\
\text { [d] I'netıkəlı 'inodıfaıd fu:d pla:nts] }\end{array}$ & $\begin{array}{l}\text { генетически модифицированое } \\
\text { продовольствие }\end{array}$ & alimentum modificata genetica & $\begin{array}{l}\text { geni dəyişdirilmiş } \text { orzaq } \\
\text { məhsulları }\end{array}$ \\
\hline $\begin{array}{l}\text { bioactive substances [baiəu'æktıv } \\
\text { s } \Lambda \text { bs'tænsız] }\end{array}$ & биоакивные вещества & substantiae bioactiva & bioaktiv maddə \\
\hline $\begin{array}{l}\text { gene transformation } \\
{\left[{ }^{\prime} d\left[\begin{array}{l}1: n \\
\left.\text { 'trænsfə' } \ln _{j}(\partial) n\right]\end{array}\right.\right.}\end{array}$ & генетическое изменение & modificatio genetica & genetik dəyişkənlik \\
\hline $\begin{array}{l}\text { GNA (glass-nonadherent cell) } \\
\text { ['gl } \alpha: \text { s nən'ædhərənt sel] }\end{array}$ & клетка, не прилипающая к стеклу & cellula nonadherernt in vitro & şüşəyə yapışmayan hüceyrə \\
\hline hybrid organizms ['haıbrid, o:ga'nızmz] & гибридные организмы & organizmus hybridus & hibrid orqanizmlər \\
\hline $\begin{array}{l}\text { immunodeficiency } \\
\left.\text { [1'mju:nə d' }{ }^{\prime} f_{1}(\curvearrowright) n(t) s 1\right]\end{array}$ & иммунодефицит & asthenia & immun çatışmazlığı \\
\hline $\begin{array}{l}\text { infringment of blood structure } \\
{\left[1 \mathrm{n}^{\prime} \text { fringmənt } \partial \mathrm{v}^{\prime} \mathrm{bl} \Lambda \mathrm{d}\right]}\end{array}$ & структура крови & haemo structura & qanın quruluşu \\
\hline $\begin{array}{l}\text { gastric membrane thickening } \\
\text { ['gæstrık'membra:n] }\end{array}$ & утолщение оболочки желудка & septum diaphragm crassificātio & mədə membranının qalınlaşması \\
\hline $\begin{array}{l}\text { genetic manipulations }\left[\mathrm{d}\left[\mathrm{I}^{\prime} \text { netık }\right.\right. \\
\text { mænıpju'le1j(ə)nz] }\end{array}$ & генетические воздействия & effecientia genetica & genetik tosir \\
\hline genetically modified potatoes & генетически модифицированные & Solanum t. modificatio & genetic modifikasiya olunmuş \\
\hline [d3ı'netıkəlı 'inodıfaiəd pə'teitəuz] & картошки & genetica & kartof \\
\hline gene transfer['d[ 1:n'trænsfə:] & перенос генов & genon transpositio & gen köçürməsi \\
\hline 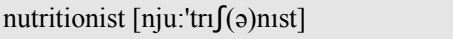 & диетолог & dietologist & dietoloq \\
\hline peach $\left[\mathrm{p} 1: \mathrm{t}_{j}\right]$ & персик & Persica & şaftalı \\
\hline persimmon [pə'sımən] & хурма & Diospyros & xurma \\
\hline plant lectins [pla:nt 'lektınz] & $\begin{array}{l}\text { фитогемагглютинин, лектин, } \\
\text { растительный гемагглютинин }\end{array}$ & plantae lectine & bitki hemoqlütenin, lektin \\
\hline pomegranate ['pomı,grænıt] & гранат & Punica granatum L. & nar \\
\hline presentiment [pri'zentımənt] & предчувствие & presentiment & əvvəlcədən hiss etmək \\
\hline quince ['qwins] & айва & Cydonia oblonga & heyva \\
\hline stomach lining ['st $\Lambda$ mət 'laının] & прослойка желудка & gastro intercalatio & mədə qat1 \\
\hline $\begin{array}{l}\text { visceral contraction } \\
{\left[{ }^{\prime} \operatorname{vis}(\partial) r(ə) 1 \operatorname{kən}^{\prime} \operatorname{træk}(\partial) n\right]}\end{array}$ & сокращение внутренних органов & vītālia contractio & daxili orqanların büzüşməsi \\
\hline $\begin{array}{l}\text { digestion system abnormalities } \\
\text { [da1'd[ e } \int(\partial) n \text { 'sıstəm əb'no:məlitız] }\end{array}$ & нарушение системы пищеварения & violatio digestivus systema & həzm sisteminin pozulması \\
\hline
\end{tabular}

A professor of the Rovett Institute of Scotland Dr Arpad Pusztai made an experiment on mice feeding them with GMo FP. Árpád Pusztai (8 September 1930) is a Hungarian-born biochemist and nutritionist who spent 36 years at the Rowett Research Institute in Aberdeen, Scotland. He is a world expert on plant lectins, authoring 270 papers and three books on the subject. In 1998 Pusztai publicly announced that the results of his research showed 
feeding genetically modified potatoes to rats had negative effects on their stomach lining and immune system. This led to Puztai being suspended and his annual contract was not renewed. The resulting controversy became known as the Pusztai affair. In 1995 the Árpád Puzstai began research on genetically modified potatoes containing the GNA (glass-non-adherent cell) lectin gene from the snowdrop plant [2]. His group fed rats on raw and cooked genetically modified potatoes, using Desiree Red potatoes as controls. In 1998 Árpád Puzstai said in an interview on a World in Action program that his group had observed damage to the intestines and immune systems of rats fed the genetically modified potatoes. He also said "If I had the choice I would certainly not eat it", and that "I find it's very unfair to use our fellow citizens as guinea pigs" [4].

This resulted in media frenzy, and Rowett Institute's director Philip James, after initially supporting Pusztai, suspended him and banned both Puztai and Susan Bardocz from speaking publicly. He also used misconduct procedures to seize the raw data [4]. The Rowett Institute published an audit criticizing Pusztai's results [5] and sent the raw data to six anonymous reviewers who also criticized Pusztai's work $[6,7]$. Pusztai responded that the raw data was "never intended for publication under intense scrutiny" [4]. Pusztai sent the audit report and his rebuttal to scientists who requested it, and in February 1999, twenty one European and American scientists released a memo supporting Pusztai [8].

Pusztai's experiment was eventually published as a letter in The Lancet in 1999 [9]. Due to the controversial nature of his research the letter was reviewed by six reviewers three times the usual number. One publicly opposed the letter, another thought it was flawed, but wanted it published "to avoid suspicions of a conspiracy against Pusztai and to give colleagues a chance to see the data for themselves" while the other four raised questions that were addressed by the authors [10]. The letter reported significant differences between the thicknesses of the gut epithelium of rats fed genetically modified potatoes, compared to those fed the control diet [9].

On the result of the experiment in the visceral contraction, digestion system abnormalities, immunodeficiency, infringement of blood structure and gastric membrane thickening of the animals were observed. And in the experiment carried out the Vienna University supported by the Australia Health Ministry has been ascertained that the mice lose their inheritance / breed ability after 3 and 4 generation.

Though use of the GMo FP is strictly forbidden in Switzerland allergic diseases are 7\% there; but in the USA where the major part of the GMo FP is produced these doses are 10 times more, id est. $70 \%$ there.

Russia is cautious about GMo foods.

Russian scientists say they must study the implications of GMo food before such food is widely introduced in their nation.
"GMo plants and animals may cause completely unexpected processes and consequences," Irina Yermakova, a Senior scientist at the Institute for Higher Neural Activity and Neurophysiology of the Russian Academy of Sciences said. She made the statement during a seminar Tuesday at a science conference in Moscow.

The scientist called for more extensive research into the impact of GMo organisms on people, the 'Novosti' news agency reported. She said an experiment, which involved feeding rats GMo soya, had revealed high mortality rates and growth retardation among offspring. Yermakova also proposed a ban on imports of transgenic products. Those attending the seminar called for adoption of safety requirements for GMo foods and mechanisms to verify compliance with such requirements, RIA Novosti said. http://hw.prometeus.nsc.ru/eng/science/scidig/05/oct2.ssi

Seeds of destruction. Secret underlying reason of genetic manipulations. Problem of food safety today as never before, is one of the problems of national safety. For last forty years the West agriculture has been considerably transformed. It has left hands of the family farmers who were cultivating mixed grain crops and carefully growing up livestock, into hands of huge global concerns of agribusiness where human work became the insignificant factor of cost. Quality of the foodstuffs has been sacrificed to its quantity and mass production. Consequences for population health are stunning, as is appreciable by distribution for last ten or more years of epidemic adiposity and illnesses in America.

Flash of new freakish illnesses on all territory of the US for last decade occurred in parallel the most extensive cultivation of GMo in the world. Today more than $70 \%$ of those average Americans eat, are GMo. They are not disturbed by it as the government forbids corresponding marks. GMo is not a technological progress. It is the manipulation based on a false science, biological reductionism which is inapplicable by definition. Independent laboratory researches, including Russian, laboratory rats who kept to a diet from GMo have proved last years, that in comparison with rats of control group, showed sharp reduction of growth of bodies, much higher infantile death rate and brain compression. Powerful international corporate campaigns in mass-media have substantially buried results of these disturbing tests.

It is necessary to consider that fact, that first patron GMo the last decades was Rockefeller's influential private Fund. Basic companies 'Duponts', 'Dow Chemical', 'Monsanto', dominating in patenting of seeds GMo and the herbicides connected with them, were decades contractors of the Pentagon and bear responsibility for creation of such poisonous products, as 'Agent Orange', dioxin and many others.

Introduction of GMo-CULTURES is accompanied by smooth propagation of that they give more crop on hectare and demand smaller quantity of chemical herbicides. Both theses are false. Seeds GMo were approved by the 
American government without any checks, since president George Bush-senior who in 1992 has let out corresponding the order. GMo - a part of the long-term program of influential leading circles in the United States, aimed at management of essential deliveries of the foodstuffs all over the world by means of the patented seeds. Rockefeller's standing behind researches GMo the same Fund, in days of the Third Reich financed Nazi eugenics. After 1945 leading figures of Fund of Rockefeller have decided to rename eugenics. The new name? Genetics.

It is not a usual reasoning on food or health. It is the documentary chronicle of how very small influential elite pursued the aim of capture of the control over a planet, using the foodstuffs. This plan was the best expressed in 1970th by the American State Secretary Henry Kissinger who has told: "Supervising the foodstuffs, you supervise the population". Today among the population of the Western Europe and Asia mass resistance GMo is observed. Patrons GMo try to break this resistance through massive propaganda pressure and officials' payoff it is entrusted to them to watch safety of health of the population in their countries. It is unsuccessful yet.

\section{Conclusion}

Once Azerbaijan was recognized with its plants of natural, ecologically pure fruit and vegetable: White Apple 'Agh Alma' apple variety of Guba; 'Gyzyl Ahmadi' apple variety and chestnut of Gabala; water-melon varieties of Sabirabad; Melon varieties of Kurdamir; pomegranate varieties of Göychay; potato varieties of Gadabay; White Onion of Hovsan Village of Absheron; crocus/saffron, 'Agh Shany' and 'Gara Shanı' grapes varieties cultivated in Baku Suburbs for centuries, almond varieties, olive varieties, 'Khar Tut' variety, fig varieties; citrus plants, tea and vegetable of Lankaran; filbert/hazel Corylus maxima Mill.(Betulaceae) varieties of Corylaceae Family, essential oils obtained of rose Rosa L. (Rosaceae) varieties, tea, persimmon et al. of Zagatala; apricot, peach and apple of Ordubad; quince, cherries, plum and alycha Aghdash; tomato, filbert/hazel Corylus maxima Mill.(Betulaceae) varieties cherry, sweet cherry et. al. of Khachmaz. Development of this list a little more is possible. Unfortunately, at present enough GMos are cultivated in this unequal land. Such foodstuffs can be often met in any market of agriculture products in Baku. The Azerbaijan Republic has got a rare potential of seemed as a heritage today remained since 'the Cold War' to change the unproductive agriculture into a valuable active like a biological natural production of GMo in healthy lands. E.Aliyev saying: "If traditional planting/sowing system will be taken some care, if we render a required attention to this area, we'll not need GMo organisms. Azerbaijan must not become a GMo organisms' polygon" [18] very fairly he speaks from the position of a patriot scientist. The problem is much more serious than we suppose; it is just the matter of "to be or not to be!" Representatives of the NATO Countries have estimated GMo as an element of a biological terrorism at their last meeting.

It is known that secret war goes among the USA and European Countries on this direction. The main goal of the countries considered as origin of the GMo - the USA, Canada and Argentina is distribution of the invented GMo seeds exporting them to all around Europe and countries being in the phase of development with the 3rd degree that will be able to cause for the massive death of the mankind. Prohibition to the GMo in our country would be able to be a basic step in fighting against such an 'import of the global death'. But this prohibition must not be carried out like some other decisions and orders on the paper; it must be implemented in the practical rule. We consider that this responsibility should be undertaken by: the Customs Office, Ministry of Agriculture, Ministry of Foreign Affairs, Ministry of Internal Affairs, Ministry of National Security, administration of the National Academy of Sciences of Azerbaijan as well as other organizations being direct connected with these problems and media.

\section{References}

[1] Dieter Deiseroth, Annegret Falter (Hrsg.) (2006). Whistleblower in Gentechnik und Rüstungsforschung Preisverleihung 2005: Theodore A. Postol, Árpád Pusztai. VMW. ISBN 978-3-8305-1262-2;

[2] Rowell, Andrew (2003). Don't worry, it's safe to eat: the true story of GM food, BSE, \& Foot and Mouth. Earthscan. ISBN 1853839329;

[3] Levidow, L.; Murphy, J.; Carr, S. (2007). "Recasting "Substantial Equivalence": Transatlantic Governance of GM Food". Science, Technology \& Human Values 32: 26. doi:10.1177/0162243906293885.

[4] "Árpád Pusztai: Biological Divide - James Randerson interviews biologist Árpád Pusztai". London: The Guardian. $15 \quad$ January 2008. http://education.guardian.co.uk/egweekly/story/0,2240547,0 0.html. Retrieved 25 April 2010;

[5] Bourne, F.J., et al (1998) Audit Report Overview Rowett Research Institute, 28 October 1998, Retrieved 28 November 2010;

[6] Bowden, Rebecca Six referees comments on Pusztai potato data e-mail from Royal Society to Pusztai, 10 May 1999, Retrieved 28 November 2010;

[7] Murray, Noreen et al, (1999) Review of data on possible toxicity of GM potatoes The Royal Society, 1 June 1999, Retrieved 28 November 2010;

[8] Enserink, M. (1999). "BIOENGINEERING: Preliminary Data Touch Off Genetic Food Fight". Science 28 (5405): 1094. doi:10.1126/science.283.5405.1094. PMID 10075564. http://www.sciencemag.org/cgi/content/summary/283/5405/ 1094. Retrieved 2009-06-26;

[9] Ewen SW, Pusztai A (October 1999). "Effect of diets containing genetically modified potatoes expressing 
Galanthus nivalis lectin on rat small intestine". Lancet 354 (9187): 1353-4. doi:10.1016/S0140-6736(98)05860-7. PMID 10533866;

[10] Martin Enserink The Lancet Scolded Over Pusztai Paper Science 22 October 1999: Vol. 286. no. 5440, p. 656 DOI 10.1126/science.286.5440.656a;

[11] The Canadian Institute for Environmental Law and Policy

[12] "Federation of German Scientists" (PDF). http://www.cbd.int/doc/external/mop-04/fgs-1-en.pdf.

[13] "Stuttgarter Friedenspreis 2009: Prof. Dr. Arpad Pusztai" (in German). http://www.die-anstifter.de/?p=3385. Retrieved 10 February 2011;
[14] NJ Jaeger (December 2009). "Global to local: Stuttgart Peace Prize honors GMO whistleblowers". LA Examiner.

[15] F.William Angdal.http://evepage.ru/biblioteka/knigi/148semena-razrusheniya-tajnaya-podopleka-geneticheskixmanipulyaczij;

http://hw.prometeus.nsc.ru/eng/science/scidig /05/oct 2.ssi

[16] We are opposite to GMo FP bioterror.www.olaylar.az. 21 April, 2011, N 61(2761) p.10.

[17] Biz GMO FP.www.olaylar.az-1n bioterror-unun əksinəyik. 21 apr. 2011,N61(2761) p.10; History of Genetics. http://en.wikipedia.org/wiki/History_of_genetics. 